\title{
Does Environmental Uncertainty Affect Entrepreneurs' Orientation and Performance? Empirical Evidence from Indonesian SMEs*
}

\author{
Rina Herani \\ Faculty of Economics and Business, Universitas Gadjah Mada, Indonesia \\ Otto Andersen \\ University of Agder (UiA), Norway
}

\begin{abstract}
Small and medium enterprises (SMEs) have a critical role in economic growth in Indonesia and become the backbone for job creation, poverty alleviation, and safeguard during the crisis. However, they are highly exposed to uncertain environments. The present study aimed to investigate the influence of SMEs' entrepreneurial orientation on business performance when uncertain environments exist. A total of 152 Indonesian SMEs were studied in order to assess this relationship. Moderated regression analysis is performed as the main statistical procedures to analyse the moderating role of environmental uncertainty on the influence of entrepreneurial orientation on business performance. Surprisingly, the result of the present study did not confirm the previous predominant studies which found that entrepreneurial orientation dimensions are positively associated with business performance in growing in an uncertain environment. Indonesian entrepreneurs were reluctant to innovate, be proactive, and take risks when an uncertain environment exists. The present study was an endeavour to provide better insight in explaining the inconsistent and ambiguous findings from existing literature.
\end{abstract}

\begin{abstract}
Abstrak: Usaha kecil dan menengah (UKM) memiliki peran penting dalam pertumbuhan ekonomi di Indonesia dan menjadi tulang punggung untuk penciptaan lapangan kerja, pengentasan kemiskinan, dan menjaga ekonomi tetap stabil selama krisis. Meskipun demikian, UKM sangat rentan terhadap ketidakpastian lingkungan. Penelitian ini bertujuan untuk menganalisis pengaruh orientasi kewirausahaan UKM terhadap kinerja bisnis dalam kondisi yang tidak pasti. Sebanyak 152 UKM Indonesia diteliti untuk menilai hubungan tersebut. Moderated Regression Analysis digunakan sebagai prosedur statistik utama untuk menganalisis peran moderasi ketidakpastian lingkungan terhadap hubungan antara orientasi kewirausahaan terhadap kinerja bisnis.Hasil pada penelitian ini tidak mengkonfirmasi penelitian sebelumnya yang pada umumnya menemukan bahwa dimensi orientasi kewirausahaan berpengaruh positif terhadap kinerja bisnis dalam kondisi lingkungan yang tidak pasti. Penelitian ini menemukan bahwa pemilik UKM di Indonesia enggan untuk berinovasi, proaktif, dan mengambil risiko ketika dihadapkan pada lingkungan yang tidak pasti. Penelitian ini merupakan upaya untuk memberikan pemahaman yang lebih baik dalam menjelaskan literatur terdahulu yang cenderung memberikan hasil dan penjelasan yang tidak konsisten dan ambigu.
\end{abstract}

Keywords: business performance; entrepreneurial orientation; environmental uncertainty

*) Part of this article has been presented in International Conference on Asia Pasific Business Innovation and Technology Management (APBITM 2010) in Cebu, Philippines (Proceedings ISBN 978-971-94544-0-3)

Corresponding authors. E-mail: rina.herani@ffeb.ugm.ac.id

ISSN: 1141-1128

http://www.gamaijb.mmugm.ac.id/ 


\section{Introduction}

Small and medium-sized enterprises (SMEs) play a vital role in economic development and income growth in many countries (Indarti and Langenberg 2004; Swierczek and $\mathrm{Ha}$ 2003; and Tambunan 2006). In the Indonesian context, SMEs make up more than 99 percent of national business entities, employ more than 96 percent of the total workforce, and contribute to USD 113 billion to exports (Depkop 2007). During the economic crisis in 1997, SMEs became a backbone for job creation, poverty alleviation, and safeguard during the crisis. Manning (2000) reported that during the Asian economic crisis, unemployment in South Korea more than tripled and more than doubled in Malaysia and Thailand. In contrast, the crisis did not affect the Indonesian labor market so badly. In 1997-1998, unemployment rose only slightly to 5.5 percent in August 1998 from just 5 percent a year earlier. Beside the agricultural sector, Manning (2000) noted that SME is a labour-intensive sector which is able to absorb a large number of workers during the economic crisis.

The man behind this success is the entrepreneur who has a critical role in managing and directing the business venture to achieve business performance. The developments of entrepreneurship and human skill improvement have become two major critical factors for a country which is striving to establish 'a sustainable economic and social development' (Tambunan 2007). Hence, it is not a surprise that the topic of entrepreneurial orientation has gained remarkable interest from scholars since they found that entrepreneurial orientation strongly associated with a firm's superior development and performance (Covin and Miles 1999; Covin and Slevin 1991; and Wiklund 1999). Covin and
Miles (1999) and Wiklund (1999) reported that entrepreneurial orientation is closely related to first-mover advantage and the propensity to take advantage of emerging opportunities which in turn will strengthen competitive position and deliver positive influence on business performance. By having entrepreneurial orientation, entrepreneurs willing to "look for information that can help them better meet the needs of their customers, manage risk taking, as well as challenge their competitors" (Tat Keh et al. 2007).

However, the previous studies related to entrepreneurial orientation have several drawbacks. First, study on entrepreneurial orientation has been concerned primarily with large firms; relatively few studies have been conducted that are specific to small and medium-sized businesses (Becherer et al. 2001). Second, this construct was widely examined in the United Stated and Western Europe context. Since the number of countries with emerging economies in Asia, Eastern Europe, and South America is growing, the generalizability of entrepreneurial orientation rests on the constructs' applicability to the developing world (Grewal and Tansuhaj 2001). Third, much of the previous literature employed unidimensional entrepreneurial orientation constructs and unidimensional performance constructs which may cause bias in the results (Covin and Slevin 1989). Moreover, a number works merely rely on financial performance to measure business success (Zahra and Covin 1995). Fourth, the previous studies of entrepreneurial orientation have ignored the importance of environmental uncertainty which may influence these constructs. Van Gelderen et al. (2000) noted that uncertainty is a fact of economic life; hence entrepreneurs are needed for arbitrage, to take risk and to innovate. 
In Indonesian context, the influence of the external environment was experienced by SMEs during the year 2003-2008. The economic, political, and social environments have created major sources of uncertainties. There are several kind of environmental uncertainty faced by Indonesian entrepreneurs: unstable oil prices which have a knock down effect on electricity bills, raw material prices, and transportation fees; regulated and 'unregulated fees' from local government and time consuming government bureaucratic processes. Other external environments are advance of technology, price competition from China's product, and global financial crisis make the external environment even more uncertain for Indonesian SMEs.

To the best of our knowledge, a comprehensive study into environmental uncertainty, entrepreneurial orientation, and business performance of Indonesian SMEs has not yet been undertaken. Investigating the aforementioned uncertainties is interesting and worthwhile since we can get an understanding of how it influences the propensity to innovate, be proactive, take risk, and business performance. The objective of the present study is to investigate the influence of entrepreneurial orientation on business performance in increasingly uncertain environments. It is hoped that the findings of the present work will contribute valuable insights to enrich and extend the previous studies in the field of entrepreneurship. The practical implications from empirical examination should provide entrepreneurs with insight into the flexible and appropriate strategies to cope with the uncertain environment

\section{Definition of SMEs in Indonesian Context}

Small and Medium Scale Enterprises in the present study combines the definition of SME by Indonesian Central Bureau of Statistics (BPS) and State Ministry of Cooperatives and Small \& Medium Enterprises (Menegkop and UKM) which is defined as economic activity run by an individual, household, or institution which has an objective to produce goods for commercial purposes which employ more than 4 but less than 100 employees and have initial assets of less than Rp 200 million (approximately USD 21,000 at the current exchange rate). This definition was used as the basis for selecting the sample of SMEs in the present study.

\section{Conceptual Framework}

The conceptual framework of the relationship being examined in the present study is illustrated in Figure 1. The entrepreneurial orientation is treated as a predictor variable. It consists of three dimensions: innovativeness, proactiveness, and risk taking. The criterion variable is business performance which consists of financial and non-financial performance. The present study conceptualised that influence of entrepreneurial orientation dimensions toward business performance depending on the value of environmental uncertainty. In other words, environmental uncertainty moderates the relationship between entrepreneurial orientation and business performance. 
Figure 1. Conceptual Framework of The Study

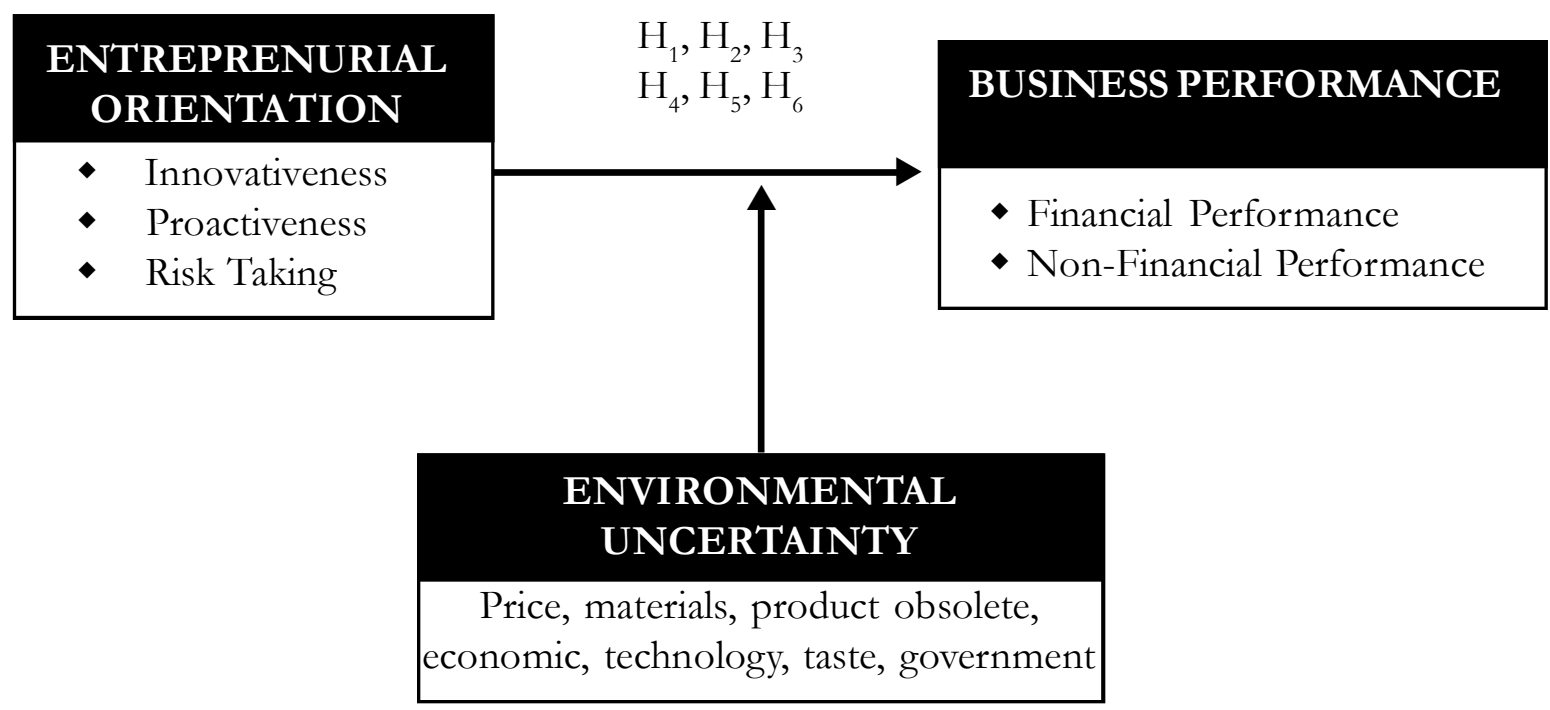

\section{Business Performance (BP)}

Business Performance (BP) has been widely used in entrepreneurship studies to measure the success level of the company. The business performance can be defined as something that financially or non-financially provides benefit for the company short-term or long-term (Appiah-Adu 1998). Lumpkin and Dess (1996) note that business performance is a multidimensional construct and the entrepreneurial process may lead to favourable or unfavourable impact on different aspects performance. Therefore, employing unidimensionality of performance would result in "misleading descriptive and normative theory building" (Lumpkin and Dess 1996: 153). Due to this consideration, the present study employed both financial performance and non-financial performance in order to capture a comprehensive understanding of the influence of constructs on both of the performances. Financial performance measured the return on assets, return on investment, return on equity; profitability; sales volume; market share, and net income (Kohli and Jaworski 1993; Narver and Slater 1990; Raju et al. 1995; Ruekert 1992; Slater and Narver 1994). While non-financial performance usually measures market access, providing secure jobs to employees, employee productivity, job creation, contribution to community development, achieve start-up goals, and innovative leadership (Appiah-Adu 1998; Jantunen et al. 2005; Murphy and Callaway 2004; Swierczek and Thanh $\mathrm{Ha}$ 2003; Tat Keh et al. 2007).

\section{Entrepreneurial Orientation (EO)}

Lumpkin and Dess (1996) described Entrepreneurial Orientation (EO) as "processes, practices, and decision-making activities that lead to new entry opportunity." The concept of EO is embodied in the firm-level processes, practices, decision-making style (Lumpkin and Dess 1996), and strategic orientation (Wiklund 1999) of an entrepreneurially-oriented firm. Entrepreneurial Orientation consists of three key dimensions of: innovativeness, proactiveness and risk-taking (Covin and Slevin 1989; Wiklund 1999). 
The present study will employ the EO measurement and classification by Covin and Slevin (1989) since this measurement consists of comprehensive dimensions which are suitable to be implemented for small companies (i.e. SMEs). Lumpkin and Dess (1996) defined innovativeness as a firm's “tendency to engage in and support new ideas, novelty, experimentation, and creative processes that may result in new products, services, or technological processes." Venkatraman (1989: 949) defined proactive-ness as the propensity to anticipate future needs by "seeking new opportunities which may or may not be related to the present line operations, introduction of new product and brands ahead of competition, strategically eliminating operations which are in the mature or declining stages of life cyle" in the operating environment, and to pioneer new methods and techniques." Lumpkin and Dess (1996) described risk taking propensity as the willingness to make investments in projects that have uncertain outcomes or unusually high profits and losses. Miller and Friesen (1978: 923) defined risk taking as "the degree to which managers are willing to make large and risky resource commitments."

\section{Perceived Environmental Uncertainty (PEU)}

The concept of (Perceived Environmental Uncertainty) PEU has been intensively examined by several researchers (Matthews and Scott 1995; Miliken 1987; Gordon and Narayanan 1984; Taylor 1984; Miles and Snow 1978; Duncan 1972; and Conrath 1967). Miliken (1987) defined uncertainty as an individual's perceived inability to predict something accurately. An individual experiences uncertainty because he/ she perceives himself/herself to be lacking sufficient information to predict accurately or because he/she feels unable to discriminate between relevant data and irrelevant data (Gifford et al. 1979).

The perceived environmental uncertainty in the present study is conceptualized as moderating the variable of entrepreneurial orientation-business performance relationship. The present study combines the measurement developed by Gordon and Narayanan (1984) and Miller and Friesen (1984). These measures are comprehensive but have smaller set of items. Thus, these will increase technical rigor and constitute parsimonious measure. In addition, these measures are suitable with issues of environmental condition faced by Indonesian SMEs.

\section{The perceived environmental uncertainty as moderator on relationship between entrepreneurial orientation and business performance}

Previous empirical studies have examined the relationship between entrepreneurial orientation and environmental uncertainty and specifically the propensity of firms confronted with environmental uncertainty to adopt entrepreneurial orientation. Major entrepreneurship studies reported that environmental uncertainty was found to increase the propensity of business firms to become more entrepreneurial through increase innovativeness, proactiveness, and acceptance of risky measures (Covin and Slevin 1989; Khandwalla 1977; Foxall 1984; Miller 1983; Smart and Vertinksy 1984; and Yusuf 2002).

Covin and Slevin (1989) found that under uncertain conditions, performance among small businesses was positively related to an entrepreneurial strategic posture. A further study by Smart and Vertinksy (1984) found that the adoption of entrepreneurial orientation by a firm posed by an increasing environmental uncertainty is not only a func- 
tion of the entrepreneurial personality but also a conscious strategic response to environmental uncertainty. Lawrence and Lorsch (1967) argued that "congruence or fit among key variables, such as environment, structure, and strategy, is critical for obtaining optimal performance."

However, a small number of works have findings that are inconsistent with the aforementioned studies (Kreiser et al. 2002 Miles et al. 1993). Kreiser et al. (2002) found that environmental hostility is negatively associated with level of innovativeness and risk taking. Miles et al. (1993) reported that the degree of environmental hostility and the propensity to adopt entrepreneurial orientation was negatively correlated.

Based on the major aforementioned literature review, the present study proposes that:

$H_{1:}$ High innovativeness is positively associated with the financial performance of the firms facing increasingly perceived environmental uncertainty.

$H_{2:}$ High proactiveness is positively associated with the financial performance of the firms facing increasingly perceived environmental uncertainty.

$H_{3:}$ High risk taking is positively associated with the financial performance of the firms facing increasingly perceived environmental uncertainty.

Extending the previous studies, the present study suggests that in increasing environmental uncertainty, entrepreneurial orientation not only be expected to provide evidentially positive influence on financial performance, but also on non-financial performance. Indeed, Indonesian SMEs are characterized with as labour intensive; consequently creating employment is an important goal (Tambunan 2006).
$\mathrm{H}_{4}$. High innovativeness is positively associated with the non-financial performance of the firms facing increasingly perceived environmental uncertainty.

$\mathrm{H}_{5} \cdot$ High proactiveness is positively associated with the non-financial performance of the firms facing increasingly perceived environmental uncertainty.

$H_{6}:$ High risk taking is positively associated with the non-financial performance of the firms facing increasingly perceived environmental uncertainty.

\section{Method}

\section{Data Collection}

The present study used a structured questionnaire as the instrument of study. The questionnaire was translated into Indonesian language. The use of a back-translation procedure involving a native English speaker ensured that the meanings of the item statements were not altered. A participant information sheet was provided to inform them of the purpose of the study and other details related to the ethical issues to the participants.

Yogyakarta province is used as the setting of the study because it has only few large enterprises and most economics activities are run by SMEs (Indarti and Langenberg 2004). Yogyakarta province is well known in Indonesia for its handicraft producers who export their products worldwide. A purposive sampling method was employed. The sampling criteria are: the participants are the owners or managers of handicraft SMEs in the province of Yogyakarta; the SMEs must be established 
at least 5 years ago; they employ more than 4 but less than 100 employees; and they has initial asset less than USD 20,000. The SMEs must have been established 5 years ago since both environmental uncertainty and business performance measurements required the participants to assess these factors during the last 5 years (2008-2003). Moreover, we need to avoid the start-up effects where environment factors influences the firm merely internal rather than external factors.

To test the wordings of the items, a pilot study was conducted involving $10 \mathrm{SME}$ owners. The wording was accordingly. Instead of using mail survey, the main study was conducted through personal direct interview at the firms' location in order to obtain greater participation. Some cases, e.g. the participants are busy or not available on location, a "drop and collect" procedure then chosen. If there were missing values in the submitted questionnaire, a follow up call was made to complete the missing data.

\section{Profile of Respondents and Enterprises}

The totals of 180 questionnaires were distributed to the participating entrepreneur. However, only 163 completed questionnaires were collected. The responses rate was 90.5 percent. Eleven participats with incomplete quetionnaire could not be contacted hence these questionnaires were dropped. The usable sample was 152 questionnaires. The profile of entrepreneurs comprised 63 percent male and 37 female. With respect to the length of operation of the firms, the profile consists of 35 percent less than 10 years, 48 percent between 10 to 20 years, and 17 percent more than 20 years.

\section{Measures}

\section{Business performance}

The present study will apply both financial performance and non-financial performance which adopted from Jantunen et al. (2005) and Swierczek and Thanh Ha (2003) which have proven to have high reliability of Cronbach $\alpha=0.91$ and Cronbach $\alpha=0.78$. The financial performance consists of two indicators which measure the perceived improvement of sales volume and profitability during the last five years. The non-financial performance consists of two indicators which measure the perceived improvement of market access and job creation during the last five years. A subjective approach will be used to measure business performance due to the difficulty in obtaining objective data from documentary sources, due to the possibility that the recorded financial and accounting data on daily basis are not available, and also because of the reluctance of organizations to divulge such information which was classified as confidential (i.e. assets, profits, sales volume). Responses to each question will be measured on a five-point Likert-type improvement scale, with response options ranging from 1 (Much Worse) to 5 (Much Better) for all items. The present study considers that five years duration could capture better information and be aligned with perceived environmental uncertainty measures (developed by Gordon and Narayanan 1984) which previously used a duration of five years to measure the environmental uncertainty.

\section{Entrepreneurial Orientation}

EO measure was adopted from Covin and Slevin (1989) which has been proved to 
develop related and distinct measures of strategic orientation with all items loaded above 0.5 and reliability coefficient of 0.87 . EO measure consist of nine items which divided into three key dimensions namely innovativeness ( 3 items), proactiveness ( 3 items), and risk-taking ( 3 items). The Innovativeness measures the extensiveness of using advanced production technology; the frequency of a company in innovating new product; and the intensity of a company in improving the existing product. The proactiveness measures the aggressiveness of a firm to be the first in introducing new product or technology; the aggressiveness to start the head-to-head competition; and the proclivity to be the first in initiating action. The risk taking dimension measures the extent to which the owner or manager is willing to take risky project, the extent to which the owner or manager is inclined to make risky investment, and the extent to which the owner or manager is inclined to make decision under the uncertain business environment. Responses of each question were measured on a five-point Likert scale.

\section{Perceived Environmental Uncertainty}

The present study adopts the PEU measure from Gordon and Narayanan (1984). This measure has been proven of having Cronbach á 0,77 . This scale measures the stability of production technology; the severity of price competition; severity raw material supply; the rate of product become out-ofdate; the stability of economic condition; the influence of government regulation; the dynamics of customer's preference; and the market activities of competitors. Respondents were asked to respond about their stance towards uncertainty conditions on a five-point Likert scale.

\section{Data Analysis}

\section{Confirmatory Factor Analysis}

The factor analyses were performed on the composite variable of business performance, entrepreneurial orientation, and perceived environmental uncertainty and resulted in the validity analysis below:

The factor analysis reported that KMO and Bartlett's test of above variables were greater than 0.60 and were significant at $p<0.01$ level which indicated that validity analysis could be continued on examining communalities and factor loadings. All five items which measured Business Performance have communality greater than 0.30 . The rotated component matrix reported that items for financial and non-financial were correctly loaded into different components. All nine items which measure entrepreneurial orientation were found to have acceptable communalities greater than 0.30 . The rotated component matrix reported that innovativeness, proactiveness, and risk taking were correctly loaded into different components. During the process, two items of perceived environmental uncertainty were deleted due to the existence of cross loading with values greater than 0.35 . The rest were loaded into one component and employed for further analysis. The split-half method analysis was use to analyse the reliability of the measure. The result reveals that the dimensions of entrepreneurial orientation, dimensions of business performance, and perceived environmental uncertainty have good reliability with Cronbach alpha ranging from 0.806 to 0.945 .

\section{Hypotheses Testing}

Moderated Regression Analysis (MRA) is employed because the conceptual frame- 
Gadjah Mada International Journal of Business -Jamuary-April, Vol. 14,No. 1,2012

Table 1. Confirmatory Factor Analysis and Scale Reliability

\begin{tabular}{lll}
\hline Construct & Component Loading & Cronbach Alpha \\
\hline
\end{tabular}

BUSINESS PERFORMANCE (BP)

Financial Performance

BP_1

0.948

BP_2

0.931

Non-Financial Performance

0.954

BP_3

0.922

BP_4

0.939

\section{ENTREPRENEURIAL ORIENTATION (EO)}

Innovativeness

0.828

EO_1

0.620

EO_2

0.763

EO_3

0.679

Proactiveness

EO_4

0.777

EO_5

0.671

EO_6

0.778

Risk Taking

0.862

EO_7

0.737

EO_8

0.777

EO_9

0.706

\section{PERCEIVED ENVIRONMENTAL UNCERTAINTY (PEU)}

PEU_2

0.675

PEU_3

0.753

PEU_4

0.726

PEU_5

0.624

PEU_6

0.799

PEU_7

0.674

Source: processed data (2008) 
work in the present study involves interaction effects so-called 'moderator effect'. The interaction effects exist because there is interaction of the third variable (moderating variable) which changes the relation between two original variables (predictor variable and criterion variables) (Tabachnick and Fidell 2007). The present study used MRA to examine the existence of the interaction effect between EO (Entrepreneurial Orientation) dimensions and Perceived Environmental Uncertainty (PEU) in its relation to business performance (BP).

Due to the possibility of a multicollinearity problem, the predictors in the present study were 'centered' before calculating the interaction effects. The term "centering" refers to the method of subtracting the variable mean from each case's value on that variable (Jaccard et al. 1990).
Moderated regression analysis was performed by conducting hierarchical regressions. The existence of a moderating role of perceived environmental uncertainty on entrepreneurial orientation and business performance relationship can be seen from the significance of interaction between perceived environmental uncertainty and each dimensions of entrepreneurial orientation on each regression (Jaccard et al. 1990).

Hypothesis 1 suggested that firms with high innovativeness in an increasing environmental uncertainty would be positively correlated with financial business performance and Hypothesis 2 predicted that proactive firms in an escalating environmental uncertainty would have greater financial performance. Table 2 indicates no statistically significant support for both hypotheses since the interaction effects of innovativeness-envi-

Table 2. Result of Moderated Regression Analysis - Perceived Environmental Uncertainty

\begin{tabular}{|c|c|c|c|c|c|c|c|c|}
\hline \multirow{3}{*}{ Variables } & \multicolumn{4}{|c|}{ Financial Performance } & \multicolumn{4}{|c|}{ Non-Financial Performance } \\
\hline & \multicolumn{2}{|c|}{ Sales Growth } & \multicolumn{2}{|c|}{ Profitability } & \multicolumn{2}{|c|}{ Market Access } & \multicolumn{2}{|c|}{ Job Creation } \\
\hline & $\mathrm{b}$ & $R^{2}$ & $\mathrm{~b}$ & $R^{2}$ & $\mathrm{~b}$ & $R^{2}$ & $\mathrm{~b}$ & $R^{2}$ \\
\hline Innovativeness & 0.401 & 0.175 & 0.434 & 0.207 & $0.369 * *$ & 0.253 & $0.373 * *$ & 0.270 \\
\hline $\begin{array}{l}\text { Perceived Environmental } \\
\text { Uncertainty }\end{array}$ & 0.030 & & 0.031 & & $0.212 *$ & & $0.229 *$ & \\
\hline $\begin{array}{l}\text { Innovativeness X } \\
\text { Perceived Environmental } \\
\text { Uncertainty }\end{array}$ & -0.078 & 0.181 & -0.127 & 0.223 & $-0.186 *$ & 0.287 & $-0.183 *$ & 0.303 \\
\hline Proactiveness & 0.132 & 0.049 & 0.193 & 0.073 & 0.160 & 0.153 & $0.190 *$ & 0.176 \\
\hline $\begin{array}{l}\text { Perceived Environmental } \\
\text { Uncertainty }\end{array}$ & 0.133 & & 0.135 & & $0.299 * *$ & & $0.309 * *$ & \\
\hline $\begin{array}{l}\text { Proactiveness X } \\
\text { Perceived Environmental } \\
\text { Uncertainty }\end{array}$ & -0.114 & 0.062 & -0.093 & 0.082 & $-0.157 *$ & 0.177 & $-0.156 *$ & 0.200 \\
\hline
\end{tabular}


Table 2 (Continued)

\begin{tabular}{llccccccc}
\hline & \multicolumn{3}{c}{ Financial Performance } & \multicolumn{3}{c}{ Non-Financial Performance } \\
\cline { 2 - 9 } Variables & \multicolumn{2}{c}{ Sales Growth } & Profitability & Market Access & \multicolumn{2}{c}{ Job Creation } \\
\cline { 2 - 9 } & $\mathbf{b}$ & $\boldsymbol{R}^{2}$ & $\mathbf{b}$ & $\boldsymbol{R}^{2}$ & $\mathbf{b}$ & $\boldsymbol{R}^{2}$ & $\mathbf{b}$ & $\boldsymbol{R}^{2}$ \\
\hline Risk Taking & $0.431 * *$ & 0.165 & $0.417 * *$ & 0.158 & $0.408 * *$ & 0.207 & $0.372 * *$ & 0.230 \\
Perceived Environmental & 0.066 & & 0.089 & & $0.254 *$ & & $0.284 * *$ \\
Uncertainty & & & & & & & & \\
Risk Taking X Perceived & & & & & & & & \\
Environmental & $-0.182 *$ & 0.196 & $-0.207 *$ & 0.198 & $-0.227 *$ & 0.257 & $-0.233 *$ & 0.280 \\
Uncertainty & & & & & & & & \\
\hline
\end{tabular}

Source: processed data (2008)

Notes: Regression weights shown are standardized coefficients obtained at the final step.

$$
\mathrm{N}=152 ;{ }^{*} p<0.05 ; * * p<0.001
$$

ronmental uncertainty and proactiveness-environmental uncertainty were found to be not significant. Hypothesis 3 proposed that firms which are willing to take risk in increasing environmental uncertainty would reap greater financial performance. This hypothesis was not supported because the moderated regression analysis reports the opposite. The interaction of risk taking-environmental uncertainty reported statistically negative affected financial performance.

Hypothesis 4 suggested that innovative firms in increasing environmental uncertainty would have greater non-financial performance. This hypothesis was not supported due to the interaction effect of innovatinessperceived environmental uncertainty was negative related to non-financial performance. This result was the opposite to the hypothesis. The same results occurred for Hypothesis 5 and hypothesis 6 . Hypothesis 5 proposed that firms which have high proactiveness in increasing environmental uncertainty would enhance the non-financial performance. This hypothesis was not sup- ported because the interaction effect of proactiveness and non-financial performance was statistically negative related to non-financial performance. Hence, it is contrary to the hypothesis. Hypothesis 6 suggested that firms which engage in high risk taking in an increasing environmental uncertainty would improve the non-financial performance. This hypothesis is not supported because the interaction effect of risk taking and non financial performance shows evidence of a negative influenced on the non-financial performance. This result was opposed the hypothesis.

\section{Discussion}

In general, the moderating effects of perceived environmental uncertainty on entrepreneurial orientation dimensions - business performance relationships were reported to be negatively associated with business performance when perceived environmental uncertainty exists. These findings indicated that among Indonesian entrepreneurs, proposing new ideas and/or getting involved in 
creative processes tend to be considered less favourably in an increasingly uncertain environment. The same result was revealed for proactiveness. Entrepreneurs are less reactive in responding opportunities when the environment is uncertain. The interaction effects between risk taking and perceived environmental uncertainty are negative in terms of all business performance indicators. This implies that Indonesian entrepreneurs have a preference not to invest or not to get involved in a project that has uncertain outcomes. In other words, in an uncertain environment, Indonesian entrepreneurs are discouraged from being innovative, proactive, and taking risks given that it would damage their business performance.

Surprisingly, these results did not confirm the previous predominant studies which found that entrepreneurial orientation dimensions were positively associated with business performance in a growing environment uncertainty (i.e. Yusuf 2002; Covin and Slevin 1989; Miller 1983; and Khandwalla 1977). The present study proposes several arguments that may cause these inconsistencies:

First, the inconsistent results may be caused by the use of aggregated measures for entrepreneurial orientation as employed by Covin and Slevin (1989) and Yusuf (2002) instead of sub-dimensions of entrepreneurial orientation (i.e. innovativeness, proactiveness, and risk taking). Kreiser (2002) noted that employment of entrepreneurial orientation dimensions tend to "vary independently of one another in a given context'.

Second, an uncertain environment is characterized as having scarcer resources and less profit margins that lead firms to be more careful in resource conservation (Miller and Friesen 1983). Hence, strongly emphasizing intensive innovative ideas, forceful proactive- ness, and extensive risk taking in this uncertain period would be considered hazardous and poor strategic choices and consequently would erode the business performance (Goll and Rasheed 1997; Kreiser et al. 2002; Miles et al. 1993; Miller and Friesen 1983; Slater and Narver1994; Zahra and Bogner 1999; Zahra and Garvis 2000).

Third, the present study found that in an uncertain environment, entrepreneurs are discouraged from adopting proactive orientation because in an uncertain environment, firms are facing fierce competition and the asymmetries are more hostile and more unpredictable. Therefore, interlocking organizational behaviour and less slack for experimental new strategy to preserve resources are preferable (Bourgeois 1981; Pfeffer and Leblebeci 1973).

Fourth, the inconsistent findings across the study in the entrepreneurship field could be simply caused by the difference of cultural background where the studies were conducted. Lee and Peterson (2000) proposed that an entrepreneurship study should acknowledge the entrepreneur as an individual and part of social environment whose personalities and behaviour intertwined and originate from national culture.

\section{Conclusion and Implication}

The key conclusion of the present study is that the entrepreneurs were discouraged to adopt innovativeness, proactiveness, and risk taking in an increasingly uncertain environment. This finding contradicts with major entrepreneurship studies. However, this result is consistent with behavioral considerations from previous scholars (Lumpkin and Dess 2001; Miller and Friesen 1983; Slater and Narver 1994). 
The findings of the present study make several important contributions in the theoretical area. First, the present study provides better insight into explaining the inconsistent and ambiguous findings of the major existing literature. Second, the present study extends the study into entrepreneurial orientation by employing entrepreneurial orientation dimensions (innovativeness, proactiveness, and risk taking) instead of an aggregated entrepreneurial orientation construct and looking at financial and non-financial performance which have rarely been investigated in previous studies. Third, this study was performed in developing countries and in the small and medium sized sector which has been less frequently examined by previous studies.

The practical implication can be drawn from this study. Entrepreneurs should carefully examine and select the information about the current situation in the market in order to make precise decisions in responding it. Overstating the current situation could impact in ineffective strategy choice and squandered business opportunities.

\section{Suggestion for Future Research}

The following limitations need to be acknowledged when interpreting the findings of the study. First, the perceived environmental uncertainty is a multidimensional construct and should be evaluated separately in order to have meaningful analysis. Instead of using aggregate environmental uncertainty, the further study should examine, for example, the moderating role of technological uncertainty or competition uncertainty in the entrepreneurial orientation and business performance relationship. Second, national culture and other internal factors (firms and entrepreneurs characteristics) should be incorporated in order to have a better understanding of the relationship. Third, the number of participants in the study was relatively small and focused only on one province. The findings may not be generalised in the Indonesian context, as differences in responses to the interviews between one region to others may exist. Hence, it would be interesting if, in the future, further study also recruited the participants from provinces where SMEs are a critical sector for the regions. Fourth, the present study employs cross-sectional design which may not allow causal inferences. Therefore, for further studies, the longitudinal approach would provide a better understanding of the nature of these relationships.

\section{References}

Appiah-Adu, K. 1998. Marketing orientation and performance: Empirical test in transition economy. Journal of Strategic Marketing 6: 25-45.

Becherer, R. C., D. Halstead, and P. Haynes. 2001. Marketing orientation in SMEs: Effect of the internal environment. Journal of Research in Marketing and Entrepreneurship 3 (1): 1-17.

Bourgeois, L. J., III. 1981. On the measurement of organizational slack. Academy ofManagement Review 6: $29-40$. 
Conrath, D. W. 1967. Organizational decision making behavior under varying conditions of uncertainty. Management Science 13: 487-500.

Covin J., and M. Miles. 1999. Corporate entrepreneurship and the pursuit of competitive advantage. Entrepreneurship Theory and Practice 23 (3): 47-63.

Covin, J. G., and D. P. Slevin. 1989. Strategic management in small firms in hostile and benign environments. Strategic Management Journal 10: 75-87.

Covin, J. G., and D. P. Slevin. 1991. A conceptual model of entrepreneurship as firm behaviour. Entrepreneurship Theory and Practice 16 (1): 7-25.

Depkop. 2007. Statistik UKM Tahun 2002-2007. Retrieved on 10 January 2008 from www.depkop.go.id.

Duncan, R. B. 1972. Characteristic of organizational environments and perceived environmental uncertainty. Administrative Science Quarterly 17: 313-327.

Foxall, G. 1984. Corporate Innovation: Marketing and Strategy. New York: St. Martins Press.

Gifford, W. E., H. R. Bobbitt, and J. W. Slocum. 1979. Message characteristics and perceptions of uncertainty by organizational decision maker. Academy of Management Journal 22: 456-481.

Goll, I., and A. M. A. Rasheed. 1997. Rational decision-making and firm performance: The moderating role of environment. Strategic Management Journal 18 (7): 583-591.

Gordon, L. A., and V. K. Narayanan. 1984. Management accounting systems, perceived environmental uncertainty and organization structure: An empirical investigation. Accounting, Organization, and Society 9 (1): 33-47.

Grewal, R., and P. Tansuhaj. 2001. Building organizational capabilities for managing economic crisis: The role of market orientation and strategic flexibility. Journal of Marketing 65 (2): 67-80.

Indarti, N., and M. Langenberg. 2004. Factors affecting business success among SMEs: Empirical evidences from Indonesia. Paper Presented at The secons Bi-Annual European Summer University. University of Twente, Enschede, The Netherlands.

Jaccard, J., R. Turrisi, and C. K. Wan. 1990. Interaction Effects in Multiple Regression: Quantitative Application in the Social Sciences. London, UK: Sage Publications. Inc.

Jantunen, A., P. Kaisu, S. Saarenketo, and K. Kylaheiko. 2005. Entrepreneurial orientation dynamic capabilities, and international performance. Journal of International Entrepreneurship 3 (3): 223-244.

Khandwalla, P.N., (1977), The Design of Organizations. New York: Harcourt Brace Jovanovich.

Kohli, A. K., B. J. Jaworski, and A. Kumar. 1993. MARKOR: A measure of market orientation. Journal of Marketing Research 30 (November): 467-77.

Kreiser, P. M., L. D. Marino, and K. M. Weaver. 2002. Reassessing the environment-EO link: The impact of environmental hostility on the dimensions of entrepreneurial orientation. Proceedings of Academy of Management.

Lawrence, P., and J. Lorsch. 1967. Organization and Environment. Cambridge MA: Harvard University Press.

Lee, S. M., and S. J. Peterson. 2000. Culture, entrepreneurial orientation, and global competitiveness. Journal of World Business 35 (4): 401-416.

Lumpkin, G. T., and G. Dess. 1996. Clarifying the entrepreneurial orientation construct and linking it to performance. Academy of Management Review 21 (1): 135-172. 
Lumpkin, G. T., and G. G. Dess. 2001. Linking two dimensions of entrepreneurial orientation to firm performance: The moderating ole of environment and industry life cycle. Journal of Business Venturing 16: 429-451.

Manning, C. 2000. Labour market adjustment to Indonesia's economic crisis: Context, trends and implications. Bulletin of Indonesian Economic Studies 36 (1): 105-36.

Matthews, C. H., and S. G. Scott. 1995. Uncertainty and planning in small and entrepreneurial firms: An empirical assessment. Journal of Small Business Management 33 (4): 34-52.

Miles, M. P., D. R. Arnold, and D. L. Thomson. 1993. The interrelationship between environmental hostility and entrepreneurial orientation. Journal of Applied Business Research 9 (4): 2-24.

Miles, R. E., and C. C. Snow. 1978. Organizational Strategy, Structure and Process. New York, McGraw-Hill.

Miliken, F. J. 1987. Three types of perceived uncertainty about the environment: State, effect, and response uncertainty. Academy of Management Review 12 (1): 133-143.

Miller, D. 1983. The correlates of entrepreneurship in three types of firms. Management Science 29 (7): 770791.

Miller, D., and P. Friesen. 1978. Archetypes of strategy formulation. Management Sciences 24: 921-933.

Miller, D., and P. Friesen. 1984. A longitudinal study of the corporate life cycle. Management Science 30: 1161-1183.

Miller, D., and P. H. Friesen. 1983. Strategy-making and environment: The third link. Strategic Management Journal 4: 221-235.

Miller, D., and P. H. Friesen. 1982. Innovation in conservative and entrepreneurial firms: two model of strategic momentum. Strategic Management Journal 3: 1-25.

Murphy, G. B., and S. K. Callaway. 2004. Doing well and happy about it? Explaining variance in entrepreneurs' stated satisfaction with performance. New England Journal of Entrepreneurship 7: 15-26.

Narver, J. C., and S. F. Slater. 1990. The effect of a market orientation on business profitability. Journal of Marketing 54 (4): 20-35.

Pfeffer, J., and H. Leblebici. 1973. The effect of competition on some dimensions of organization structure. Social Forces 52: 268-279.

Raju, P. S., S. C. Lonial, and Y. P. Gupta. 1995. Market orientation and performance in the hospital industry. Journal of Health Care Marketing 15 (4): 34-41.

Ruekert, R. W., 1992. Developing a market orientation: An organizational strategy perspective. International Journal of Research in Marketing 9 (3): 255-245.

Slater, S. F., and J. C. Narver. 1994. Does competitive-environment moderate the market orientationperformance relationship? Journal of Marketing 58 (January): 46-55.

Smart, C., and I. Vertinksy. 1984. Strategy and the environment: A study of corporate response to crises. Strategic Management Journal 5 (3): 199-214.

Swierczek, F. W., and H. T. Thanh. 2003. Entrepreneurial orientation, uncertainty avoidance and firm performance: An analysis of Thai and Vietnamese SMEs. Entrepreneurship and Innovation (February): 46-58.

Tabachnick, B. G., and L. S. Fidell. 2007. Using Multivariate Statistics ( $5^{\text {th }}$ ed.). Pearson International Edition.

Tambunan, T. T. H. 2006. Development of small-and-medium-scale industry clusters in Indonesia. Kadin Indonesia-Jetro: 1-22. Retrieved from www.kadin-indonesia.or.id 
Tambunan, T. T. H. 2007. Entrepreneurship development: SMEs in Indonesia. Journal of Developmental Entrepreneurship 12 (1): 95-118.

Tat Keh, H., T. T. Mai Nguyen, and H. Ping Ng. 2007. The effect of entrepreneurial orientation and market information on the performance of SMEs. Journal of Business Venturing 22 (4): 592-611.

Taylor, R. N. 1984. Behavioral Decision Making. Glenview. LL: Scott Foresman.

Van Gelderen, M., M. Frese and R. Thurik. 2000. Strategies, uncertainty and performance of small business startups. Small Business Economics 15: 165-181.

Venkatraman, N. 1989. Strategic orientation of business enterprises: The construct dimensionality, and measurement. Management Science 35: 942-962.

Wiklund, J. 1999. The sustainability of the entrepreneurial orientation-performance relationship. Entrepreneurship Theory and Practic 24 (1): 37-48.

Yusuf, A. 2002. Environmental uncertainty, the entrepreneurial orientation of business ventures and performance. IJCM 12 (3 and 4): 83-102.

Zahra, S. A., and W. Bogner. 1999. Technology strategy and software new ventures' performance: Exploring the moderating effect of competitive environment. Journal of Business Venturing 15: 135173.

Zahra, S., and W. Bogner. 1999. Technology strategy and software new venture performance: The moderating effect of the competitive environment. Journal of Business Venturing 15 (2): 135-173.

Zahra, S. A., and J. G. Covin. 1995. Contextual influences on the corporate entrepreneurship-performance relationship: a longitudinal analysis. Journal of Business Venturing 10: 43-58.

Zahra, S. A., and D. M. Garvis. 2000. International corporate entrepreneurship and firm performance: the moderating effect of international environmental hostility. Journal of Business Venturing 15: 469492. 